\title{
A Novel Xanthomonas sp. Causes Bacterial Spot of Rose (Rosa spp.)
}

Cheng-Hua Huang, Gary E. Vallad, Heather Adkison, Carly Summers, Elaina Margenthaler, and Christina Schneider, Gulf Coast Research and Education Center, University of Florida, IFAS, Wimauma 33598; Jason Hong and Jeffrey B. Jones, Department of Plant Pathology, University of Florida, Gainesville 32611; Kevin Ong, Texas Plant Disease Diagnostic Lab, Texas A\&M University, College Station 77845; and David J. Norman, Mid-Florida Research and Education Center, University of Florida, IFAS, Apopka 32703

\begin{abstract}
Huang, C.-H., Vallad, G. E., Adkison, H., Summers, C., Margenthaler, E., Schneider, C., Hong, J., Jones, J. B., Ong, K., and Norman, D. J. 2013. A novel Xanthomonas sp. causes bacterial spot of rose (Rosa spp.). Plant Dis. 97:1301-1307.

A bacterial spot of rose (Rosa spp.) caused by a xanthomonad was observed in Florida and Texas. Ten representative strains collected from the two states between 2004 and 2010 were used to determine the taxonomic position of this rose pathogen. Fatty acid methyl ester analysis was performed and a nearly 2-kb 16S-23S rRNA intergenic spacer along with flanking portions of the 16S and 23S rRNA genes were sequenced for selected strains, showing that they were members of the genus Xanthomonas. Multilocus sequence typing and analysis (MLST/MLSA) and pathogenicity tests were conducted to further characterize the Xanthomonas strains. The MLSA, based on six gene fragments-fusA, gapA, gltA, gyrB, lacF, and lepA—showed that the

rose strains fell into Xanthomonas axonopodis subgroup 9.2 and shared the highest similarity values $(98.8$ to $99.7 \%)$ with $X$. alfalfae subsp. citrumelonis of the subgroup. However, principal coordinate analysis grouped the rose strains into a unique cluster distinct from other members of the subgroup according to virulence phenotypes on 11 plant species belonging to five plant families (Araceae, Euphorbiaceae, Rosaceae, Rutaceae, and Solanaceae). Moreover, the rose strains were aggressive on rose and Indian Hawthorn (Rhaphiolepsis indica). On the basis of the MLSA and virulence phenotypes, the pathovar epithet rosa is proposed.
\end{abstract}

Xanthomonas is a large genus of plant-pathogenic bacteria that are gram negative, rod shaped, and yellow pigmented, causing diseases in up to 400 plant hosts (36). A number of Xanthomonas spp. pathogenic on members of the family Rosaceae have been reported, such as Xanthomonas fragariae on strawberry (33), X. pruni on peach (47), and a Xanthomonas sp. on Photinia (23). However, pathogenic Xanthomonas spp. have not been documented on rose (Rosa spp.), a member of the family Rosaceae. Specieslevel classification of Xanthomonas spp. has been based on DNADNA hybridization (DDH; 45), repetitive sequence-based polymerase chain reaction (rep-PCR; 32), and multilocus sequence typing and analysis (MLST/MLSA) (51). Some species of Xanthomonas are subdivided into pathovars (6). More than 140 pathovars have been defined within the genus Xanthomonas (46), The term pathovar was established to name pathogens that are specific for certain diseases but the classification is merely derived from the pathogenic reaction phenotype of a plant rather than the intrinsic characteristics of these pathogens $(46,52)$. This special classification was adopted as a provisional solution until more adequate data would be established. Since 1995, genomic fingerprinting and DDH have been used to delineate many pathovar groups within the genus Xanthomonas into separate species, especially within $X$. axonopodis subgroups $(7,9,11,15,31,32,45)$. Although limitations of DDH have been reported, it has played a central role in the delineation of bacterial species. However, the need for a more flexible approach to define bacterial species has been proposed to avoid the restrictions of DDH (8).

MLST/MLSA is an alternative method to classify bacteria based on comparing sequences of various chromosomal loci among

Corresponding author: G. E. Vallad, E-mail: gvallad@ufl.edu

Current address for C. Summers: Department of Plant Pathology and PlantMicrobe Biology, Cornell University, Ithaca, NY 14853.

Accepted for publication 28 February 2013.

http://dx.doi.org/10.1094/PDIS-09-12-0851-RE

(C) 2013 The American Phytopathological Society closely related organisms (20). MLSA results have been compared with species delineated by DDH for Xanthomonas spp., suggesting that MLSA mimics groupings derived from DDH, amplified fragment length polymorphism, and rep-PCR and rapidly differentiates species (51). In addition, MLSA can provide an equivalent level of the maximum possible resolution among bacterial isolates determined by whole-genome sequencing (19). More importantly, MLSA offers a relatively simple and rapid way to allocate strains to known species or group them as members of new species $(1,51)$. An MLSA database and website was recently developed for plantassociated microbes, known as the PAMDB, for identifying and comparing strains (1). MLSA data of the PAMDB can assign unknown Xanthomonas strains to any of the phylogenetic groups but it has only limited power to differentiate the strains belonging to the same pathovar or subspecies (1). Whole-genome sequencing and additional informative MLSA loci may provide the means to further facilitate identification of Xanthomonas strains and to investigate their microevolution. However, clustering may not occur or may include different groups of strains because important phenotypes such as pathogenicity determinants may not be conferred by chromosomal loci or sampled strains may reveal a continuous spectrum of genotypic variation or both (8).

A congruence of systematics using different methods reveals real phylogenetic relationships between strains tested (24,50). Due to the limitations of DDH, MLSA has offered a relatively simple and rapid way to classify strains as members of known species of Xanthomonas $(1,51)$. The polyphasic classification using DDH and phenotypic information has elevated a number of Xanthomonas pathovars to species $(15,45)$. In addition to MLSA data, determining the host range of pathogenic Xanthomonas strains is an important part of phenotypic information because the pathogen is usually specific to a number of related plants and, therefore, often codified in pathovar nomenclature (6). Virulence phenotypes and DNA sequence changes may explain host specialization processes, supporting an appropriate reflection of the pathovar classification (27).

The objectives of this study were to identify bacterial strains isolated from rose, to evaluate their host range relative to other Xanthomonas spp., and to determine the taxonomic placement of the rose strains relative to other xanthomonads based on MLSA. 


\section{Materials and Methods}

Strain isolation, storage, and DNA extraction. Bacterial strains were isolated from rose samples collected from production nurseries, local retail stores, or samples submitted to the plant diag- nostic clinics at University of Florida Research and Education Centers in Apopka and Wimauma, FL (Table 1). Strains were recovered by streaking homogenized tissue sections from the lesion margins of symptomatic plants onto nutrient agar (NA) (Difco Laboratories) and recovering the predominant, yellow-pigmented

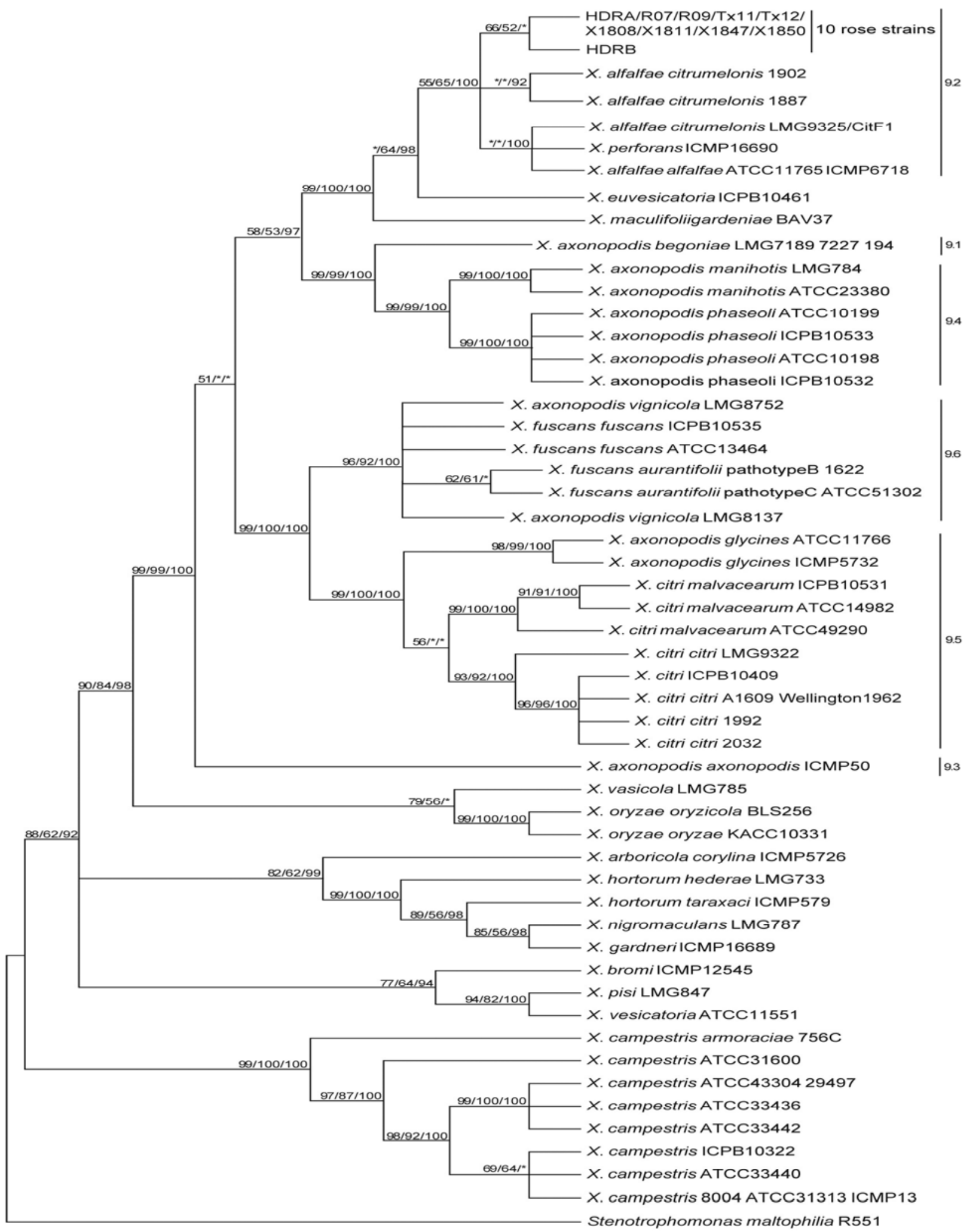

Fig. 1. Phylogeny for rose strains of Xanthomonas based on the concatenated data set of fragments of the genes fusA, gap-1, gltA, gyrB, lacF, and lepA. Nonredundant sequences of the genes of Xanthomonas were download from PAMDB (1) for alignment with sequences of rose strains in this study. Numbers on nodes represent bootstrap support values for maximum parsimony (front), maximum likelihood (middle), and Bayesian posterior probabilities presented as percentage (back). Values represented by an asterisk (*) were less than $50 \%$ for bootstrap or $90 \%$ for Bayesian posterior probabilities. Numbers 9.1 through 9.6 are the groups described by Rademaker and colleagues within Xanthomonas axonopodis (34). 
colonies typical of Xanthomonas spp. after 3 to 5 days of incubation at $28^{\circ} \mathrm{C}$. Representative colonies were subsequently streaked and incubated on NA for further purification before being stored at $-80^{\circ} \mathrm{C}$ in $30 \%$ glycerol. Other reference Xanthomonas strains (Table 1) were similarly purified prior to storage at $-80^{\circ} \mathrm{C}$. DNA was extracted using the hexadecyltrimethylammonium bromide method, as previously described (2). DNA was stored in TrisEDTA buffer (10 mM Tris and $1 \mathrm{mM}$ EDTA, $\mathrm{pH} 8.0)$ at $-20^{\circ} \mathrm{C}$.

Pathogenicity tests. The pathogenicity of recovered Xanthomonas strains (R07, R09, HDRA, and HDRB) was tested using a bacterial suspension $\left(0.01 \mathrm{M} \mathrm{MgSO}_{4}\right.$ at $\left.2 \times 10^{6} \mathrm{CFU} / \mathrm{ml}\right)$ by either infiltrating the abaxial sides of expanding rose leaves with a needless syringe or by dipping leaves into the bacterial suspension and enclosing them in plastic bags for $48 \mathrm{~h}$ to maintain humidity $(34,37)$. Similar inoculations of shrub rose with $X$. perforans strain $\mathrm{T} 4$ (XcT4) and $0.01 \mathrm{M} \mathrm{MgSO}_{4}$ were included as controls, in addition to inoculating tomato 'FL 47' with the recovered Xanthomonas strains and XcT4. All plants were maintained in a greenhouse. Strains were reisolated from symptomatic tissues as described above, thus completing Koch's postulates.

Cross-pathogenicity tests. Four rose strains (R07, R09, HDRA, and HDRB) representing the two haplotypes found in this study (Fig. 1) were prepared from NA with glucose cultures grown for 48 $\mathrm{h}$ at $28^{\circ} \mathrm{C}$, suspended, and diluted to $2 \times 10^{4}, 2 \times 10^{6}$, and $2 \times 10^{8}$
$\mathrm{CFU} / \mathrm{ml}$ in $0.01 \mathrm{M} \mathrm{MgSO}_{4}$. Various horticultural plants common to local nursery and agriculture production and representatives of several plant families were chosen to test the host range of the rose strains (Table 2). Plants were inoculated by infiltrating expanding leaves as described above; a pathogen-free $0.01 \mathrm{M} \mathrm{MgSO}_{4}$ control and a Xanthomonas strain pathogenic to the host was included as a standard (Table 2). The inoculated plants were monitored for disease development, comparing symptoms to the mock-inoculated control and Xanthomonas standard. Disease was rated using a 0-to3 scale where 0 showed no response and 3 represented moderate to severe chlorosis and necrosis. The experiment was repeated two to three times. A matrix based on the virulence differences between each pair of strains was generated using GenAlEx version 6.4 (29). This matrix was used in a principal coordinate analysis (PCA) employed in GenAlEx to visualize any clustering based on virulence difference.

Fatty acid methyl ester analysis. Selected rose strains (R07, HDRA, and HDRB) representing the two haplotypes detected in this study (Fig. 1) were subjected to fatty acid methyl ester (FAME) analysis. Whole-cell FAMEs were extracted and analyzed as described previously (5). FAME profiles of the rose strains were compared with those of known strains stored in the Sherlock Microbial Identification system (version 4.5; Microbial ID, Inc.), which were presented as similarity values.

Table 1. Xanthomonas strains used in this study

\begin{tabular}{|c|c|c|c|c|c|}
\hline Strain & Species & Host & Location & Year & Source \\
\hline R07 & Xanthomonas alfalfae pv. rosa & Rosa sp. & Florida & 2008 & G. Vallad \\
\hline R09 & X. alfalfae pv. rosa & Rosa sp. & Florida & 2008 & G. Vallad \\
\hline HDRA & $X$. alfalfae pv. rosa & Rosa sp. & Florida & 2009 & G. Vallad \\
\hline HDRB & X. alfalfae pv. rosa & Rosa sp. & Florida & 2009 & G. Vallad \\
\hline X1808 & $X$. alfalfae pv. rosa & Rosa sp. & Florida & 2004 & D. Norman \\
\hline X1811 & X. alfalfae pv. rosa & Rosa sp. & Florida & 2004 & D. Norman \\
\hline $\mathrm{X} 1847$ & $X$. alfalfae pv. rosa & Rosa sp. & Florida & 2010 & D. Norman \\
\hline $\mathrm{X} 1850$ & $X$. alfalfae pv. rosa & Rosa sp. & Florida & 2010 & D. Norman \\
\hline Tx11 & $X$. alfalfae pv. rosa & Rosa sp. & Texas & 2010 & K. Ong \\
\hline Tx12 & $X$. alfalfae pv. rosa & Rosa sp. & Texas & 2010 & K. Ong \\
\hline CitN101 & X. alfalfae subsp. citrumelonis & Citrus spp. & Florida & Unknown & J. Jones \\
\hline CitF1 & X. alfalfae subsp. citrumelonis & Citrus spp. & Florida & Unknown & J. Jones \\
\hline Man672 & X. axonopodis pv. manihotis & Manihot esculenta & Florida & Unknown & D. Norman \\
\hline Man678 & X. axonopodis pv. manihotis & M. esculenta & Florida & Unknown & D. Norman \\
\hline X476 & X. axonopodis pv. dieffenbachiae & Philodendron spp. & Florida & Unknown & D. Norman \\
\hline $\mathrm{X} 1750$ & X. axonopodis pv. dieffenbachiae & Philodendron spp. & Florida & Unknown & D. Norman \\
\hline Euv69 & X. euvesicatoria & Capsicum аппит & Florida & Unknown & P. Roberts \\
\hline Euv71 & X. euvesicatoria & C. annum & Florida & Unknown & P. Roberts \\
\hline Euv73 & X. euvesicatoria & C. annum & Florida & Unknown & P. Roberts \\
\hline $\mathrm{XcT} 4$ & $X$. perforans & Solanum lycopersicum & Florida & Unknown & J. Scott \\
\hline
\end{tabular}

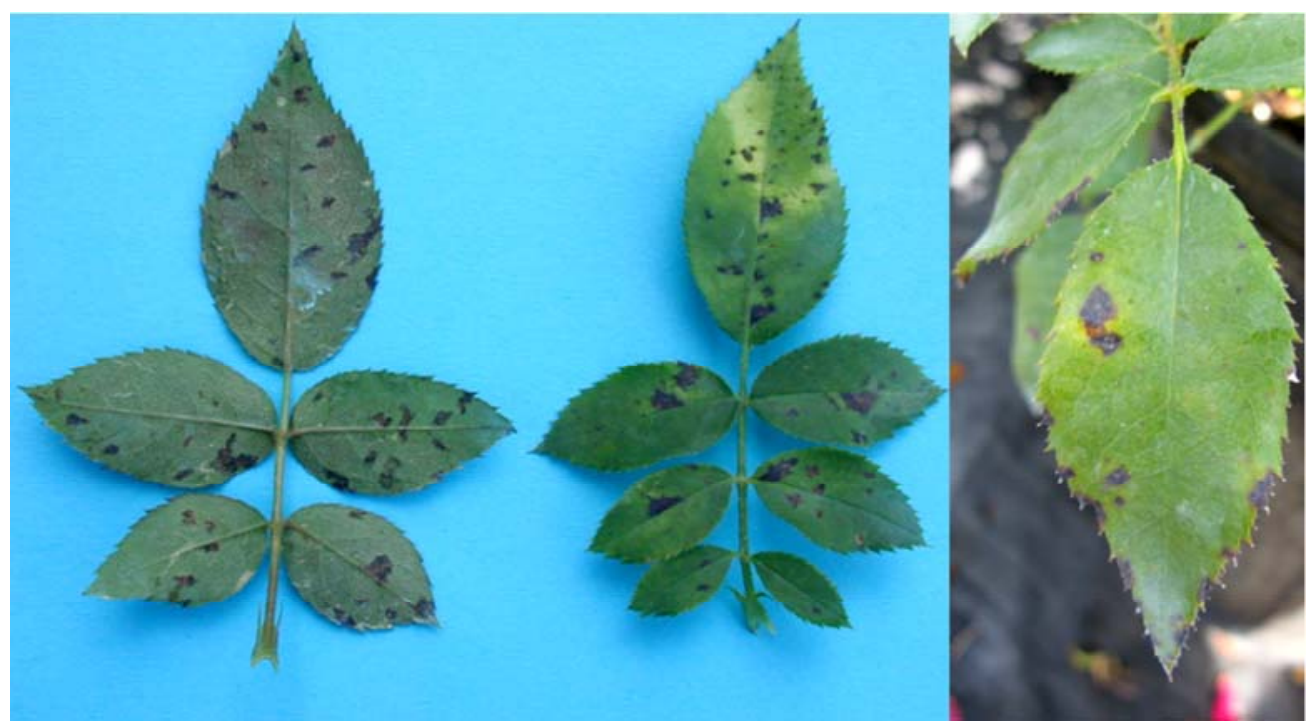

Fig. 2. Symptoms of bacterial spot on Rosa RADtko (left) and RADrazz (right). 
rRNA gene sequencing. A nearly 2-kb 16S-23S rRNA intergenic spacer (ITS) along with flanking portions of the $16 \mathrm{~S}$ and $23 \mathrm{~S}$ rRNA genes were sequenced for R07, HDRA, and HDRB. Primers and amplification conditions were used as previously described (40). Amplifications were performed in a Mastercycler ep thermocycler (Eppendorf). Amplicons were sequenced using BigDye Terminator Cycle Sequencing Chemistry and ABI 3730 XL DNA Sequencer (Applied Biosystems) at the Interdisciplinary Center for Biotechnology Research facility, University of Florida, Gainesville. Sequences were edited using Geneious version 5.3.6 (Biomatters Ltd.). The sequences of the rose strains were compared with those from GenBank using BLAST.

MLSA. Ten rose strains (Table 1) were subjected to MLST/ MLSA. Primers and amplification conditions for six gene fragments-fusA, gapA, gltA, gyrB, lacF, and lepA - were employed as previously described (1). Methods for DNA sequencing and sequence editing were performed as described above.

Nucleotide sequence accession numbers. The DNA sequence data reported in this study have been deposited in GenBank (http:// www.ncbi.nlm.nih.gov/) under accession numbers JX013568 to JX013633.

Phylogenetic analysis. Nonredundant sequences of fusA, gapA, gltA, gyrB, lacF, and lepA of Xanthomonas were downloaded from PAMDB (1) for alignment with sequences of rose strains in this study. The alignment was performed using Clustal $\mathrm{X}$ version 2.0.6 (16) and adjusted by eye using Se-Al version 2.0a10 (copyright 1996; A. Rambaut, Zoology Department, University of Oxford). Gaps were considered missing data. Prior to phylogenetic analyses, sequence diversity, including numbers of haplotypes, numbers of polymorphic sites, and nuclear diversity, was determined among all rose strains of Xanthomonas using DnaSP version 5 (17).

Parsimony analyses were conducted using MEGA5 (44). The most parsimonious tree was obtained using the close-neighborinterchange algorithm with search level 1 in which initial trees were obtained with the random addition of sequences $(1,000$ replicates). Clade stability was evaluated using 1,000 bootstrap replicates. For maximum likelihood (ML) and Bayesian analysis, jMODELTEST version 2.1.1 (30) was used to determine appropriate models of nucleotide substitution. The general time reversible (GTR) model with $\gamma$-distributed rate variation across sites and a proportion of invariable sties was chosen based on the Akaike Information Criterion (12). ML was analyzed using GARLI version 2.0 (54), in which a stochastic genetic algorithm-like approach was used to simultaneously estimate the topology, branch lengths, and substitution model parameters that maximize the log-likelihood. A bootstrap analysis was performed using 1,000 replicates Bayesian analysis was performed using MrBayes version 3.2.1 (35). The Markov chain Monte Carlo (MCMC) analysis was run with four chains for $10,000,000$ generations, sampling every 100 generations and starting with a random tree. The first 25,000 trees with low likelihoods were discarded because the burn-in of the chain since stationarity was reached after approximately generation $2,500,000$. The remaining 75,000 trees were imported to PAUP* $4.0 \mathrm{~b} 10$ (43) to generate a $90 \%$ majority-rule consensus tree. Phylogenetic trees derived from the three methods were rooted with the outgroup, Stenotrophomonas maltophilia R551.

A similarity matrix of concatenated sequence data representing Xanthomonas spp. grouped with rose strains into the same clade was prepared using MEGA5. Numbers of nucleotide differences with standard errors for all pairwise relationships were obtained using the distance estimation with 1,000 bootstrap replicates.

To test correlation between pathogenicity profile and MLSA, distance matrices were generated from the concatenated sequence of the strains used in cross-pathogenicity tests and from the pathogenicity profile (Table 2) using MEGA5 and GenAlEx, respectively. Correlations between two distance matrices were determined using the Mantel test (21) implemented in GenAlEX with 9,999 permutations.

\section{Results}

Pathogenicity and cross-pathogenicity tests. Foliar symptoms of shrub rose samples exhibited small angular black lesions from vein restriction and could often be observed along the leaf margins surrounding hydathodes (Fig. 2). Slight chlorosis was associated with lesions, except in cases where lesions coalesced, causing blighting and premature defoliation. Excised lesions exhibited bacterial streaming upon microscopic examination of wet mounts and yielded yellow mucoid colonies characteristic of xanthomonads when streaked on nutrient agar. Results of Koch's postulates confirmed that a Xanthomonas sp. was the causal agent of leaf spot of rose. Based on pathogenicity tests via leaf infiltration, rose strains of Xanthomonas were clearly more aggressive on rose and Indian Hawthorn than the other hosts tested (Table 2). Moreover, other groups of Xanthomonas strains were also more virulent on the host where they were originally isolated. Although Xanthomonas spp. used in cross-pathogenicity tests showed some extent of cross-pathogenicity, PCA results showed that the rose strains formed a distinct cluster from the other Xanthomonas spp. based on virulence phenotypes (Fig. 3).

Table 2. Cross-pathogenicity of xanthomonads across several plant families

\begin{tabular}{|c|c|c|c|c|c|c|c|c|c|c|c|c|}
\hline \multirow[b]{3}{*}{ Xanthomonas spp. } & \multirow[b]{3}{*}{ Isolate } & \multicolumn{11}{|c|}{ Plants by family } \\
\hline & & \multicolumn{2}{|c|}{ Rosaceae } & \multicolumn{2}{|c|}{ Solanaceae } & \multicolumn{3}{|c|}{ Rutaceae } & \multicolumn{2}{|c|}{ Euphorbiaceae } & \multicolumn{2}{|c|}{ Araceae } \\
\hline & & Rose & Hawth & Tom & Pep & SO & CLEO & SWG & Crown & Jatro & Lily & Poth \\
\hline alfalfae pv. rosa & R07 & 3 & 3 & 1 & 1 & 1 & 1 & 1 & 1 & 1 & 0 & 1 \\
\hline alfalfae pv. rosa & R09 & 3 & 3 & 0 & 0 & 0 & 1 & 0 & 1 & 0 & 1 & 1 \\
\hline alfalfae pv. rosa & HDRA & 3 & 2 & 2 & 0 & 0 & 0 & 1 & 1 & 1 & 0 & 1 \\
\hline alfalfae pv. rosa & HDRB & 3 & 2 & 1 & 1 & 0 & 1 & 1 & 1 & 1 & 0 & 1 \\
\hline perforans & $\mathrm{XcT} 4$ & 0 & 0 & 3 & 2 & 1 & 1 & 0 & 1 & 1 & 2 & 1 \\
\hline euvesictoria & Euv69 & 0 & 0 & 3 & 3 & 1 & 1 & 2 & 1 & 1 & 0 & 1 \\
\hline euvesictoria & Euv71 & 0 & 0 & 3 & 3 & 2 & 1 & 0 & 0 & 1 & 0 & 0 \\
\hline euvesictoria & Euv73 & 0 & 0 & 3 & 3 & 0 & 2 & 3 & 1 & 1 & 0 & 0 \\
\hline alfalfae subsp. citrumelonis & CitN101 & 1 & 0 & 3 & 1 & 3 & 3 & 3 & 1 & 1 & 2 & 1 \\
\hline alfalfae subsp. citrumelonis & CitF1 & 1 & 2 & 1 & 0 & 3 & 3 & 3 & 0 & 2 & 1 & 0 \\
\hline axonopodis pv. manihotis & Man672 & 0 & 0 & 2 & 1 & 0 & 1 & 0 & 1 & 2 & 0 & 2 \\
\hline axonopodis pv. manihotis & Man678 & 1 & 0 & 2 & 0 & 0 & 0 & 0 & 1 & 2 & 0 & 0 \\
\hline axonopodis pv. dieffenbachiae & $\mathrm{X} 476$ & 0 & 0 & 0 & 0 & 0 & 1 & 2 & 0 & 1 & 2 & 2 \\
\hline axonopodis pv. dieffenbachiae & $\mathrm{X} 1750$ & 0 & 0 & 3 & 0 & 0 & 1 & 1 & 0 & 1 & 3 & 3 \\
\hline
\end{tabular}

a Common and scientific names (in parentheses) of plants used in pathogenicity test are CLEO = Mandarin orange 'Cleopatra' $($ Citrus reshni), Crown = Crown of thorns (Euphorbia millii), Hawth = Indian Hawthorn (Rhaphiolepsis indica), Jatro = Jatropa $($ Jatropa integerrima), Lily = Peace Lily (Spathophyllum sp.), Poth = Pothos (Epipremnum aureum), Rose = Rosa Knock Out 'Radrazz' (Rosa sp.), SO = Sour orange (Citrus aurantium), and SWG $=$ Trifoliate hybrid orange 'Swingle' (Citrus paradisi $\times$ Ponciris trifoliata). Scores: $0=$ no response, $1=$ minor chlorosis or necrosis at injection site, $2=$ minor to moderate chlorosis and minor necrosis, mostly confined to injection site, and $3=$ moderate-severe chlorosis and necrosis, expanding lesion. Scores are a summation of results from two to three independent experiments. 
FAME analysis. FAME analysis showed that the three selected strains had similar fatty acid profiles, which matched the strains to $X$. alfalfae subsp. citrumelonis with similarity indices of 0.73 to 0.93 . Similarity indices greater than 0.5 were also observed as compared with other pathovars of $X$. axonopodis such as dieffenbachiae (0.64 to 0.80 ) and manihotis (0.67 to 0.77) (data not shown).

rRNA gene sequencing. The nearly 2-kb sequences of the entire ITS along with portions of 16S rRNA and 23S rRNA genes were identical among the three selected rose strains sequenced. BLAST results showed that the closest match for the rose strains was $X$. axonopodis pv. dieffenbachiae, with $100 \%$ identity. Other Xanthomonas spp. (i.e., X. perforans, X. alfalfae subsp. citrumelonis, X. gardneri, and $X$. vesicatoria) also demonstrated high percent identity matches, with as few as one to three bases different, confirming that the rose strains were members of the genus Xanthomonas.

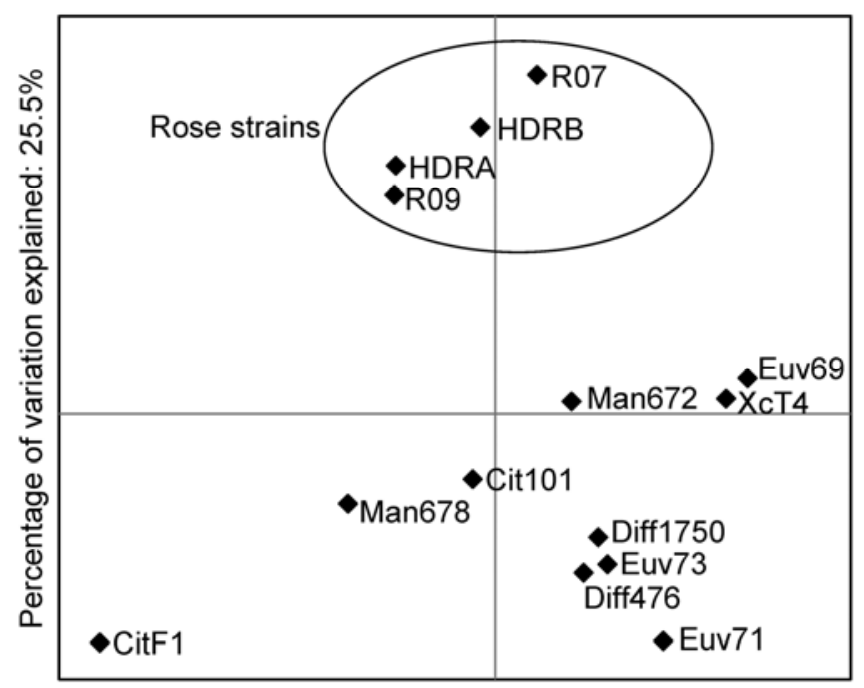

Percentage of variation explained: $29.6 \%$

Fig. 3. Principal component analysis plot of virulence phenotypes of 14 Xanthomonas strains based on differences in virulence on 11 plant species belonging to five families. Note that rose strains formed a distinct cluster from the other Xanthomonas spp.

Table 3. Sequence diversity estimates for rose strains of Xanthomonas

\begin{tabular}{lccl}
\hline Gene & $\begin{array}{c}\text { Sequence } \\
\text { length (bp) }\end{array}$ & $\begin{array}{c}\text { Number of } \\
\text { polymorphic sites }\end{array}$ & $\begin{array}{c}\text { Nucleotide }^{\text {diversity }} \\
\text { d }^{\mathbf{a}}\end{array}$ \\
\hline fusA & 591 & 0 & 0 \\
gapA & 444 & 25 & 0.01126 \\
gltA & 501 & 0 & 0 \\
gyrB & 411 & 0 & 0 \\
lacF & 408 & 0 & 0 \\
lepA & 390 & 0 & 0 \\
Combined & 2,745 & 25 & 0.00182 \\
\hline
\end{tabular}

${ }^{a}$ Nucleotide diversity was calculated based on the average number of nucleotide differences per site between two sequences (26).
Phylogenetic analyses. Analyzed sequence lengths ranged from $390 \mathrm{bp}$ (lepA) to $591 \mathrm{bp}$ (fusA), concatenating a total of $2,745 \mathrm{bp}$ for the six genes sequenced. The sequence diversity of the 10 rose strains was small, with only two haplotypes identified (Fig. 3). Of these 10 rose strains, R07, R09, HDRA, X1808, X1811, X1847, $\mathrm{X} 1850$, Tx11, and Tx12 shared the same haplotype. HDRB was a unique haplotype. The two haplotypes differed by 25 nucleotides (nt) in the 444-nt gapA sequence, with a nucleotide diversity value of 0.01126 . Variable sites were not detected in the other genes sequenced from the rose strains (Table 3 ).

Results of phylogenetic analyses obtained from maximum parsimony, ML, and Bayesian inference were congruent for rose strains, which grouped rose strains into the 9.2 clade identified by Rademarker and colleagues (32; Fig. 1). Interestingly, these rose strains formed a subclade of clade 9.2 based on maximum parsimony and ML analyses, although Bayesian analysis did not support the subclade stability. Bootstrap values inferred by maximum parsimony and ML for the 9.2 clade were 55 and $65 \%$, respectively. Moreover, the posterior probability inferred by Bayesian analysis was $100 \%$ for the clade, supporting the clade reliability. The rose strains were more phylogenetically close to $X$. alfalfae subsp. citrumelonis, $X$. alfalfae subsp. alfalfae, and X. perforans of the 9.2 clade than the other Xanthomonas spp. The internal similarity value of DNA sequences was $99.1 \%$ for the rose strains (Table 4). Similarity values for strains of the 9.2 clade were 98.3 to $99.7 \%$, with the lowest value between the rose strain HDRB and X. alfalfae subsp. alfalfae. Overall, the rose strains shared the highest similarity values (98.8 to $99.7 \%$ ) with $X$. alfalfae subsp. citrumelonis (Table 4). The correlation value $\left(R^{2}=0.127, P=0.130\right)$ obtained from the Mantel test for the relationship between crosspathogenicity and MLSA suggested that the strains of the clades 9.2 and 9.4 used in our cross-pathogenicity test might have a wide host range that was not significantly associated with genetic relatedness revealed by MLSA.

\section{Discussion}

In this study, we confirmed that bacterial spot of rose was caused by Xanthomonas spp. based on pathogenicity, FAME, and DNA sequence analyses. Koch's postulate showed that rose strains of Xanthomonas were pathogenic on rose and another member of the family Rosaceae, Indian Hawthorn, and that Xanthomonas spp. were consistently reisolated. Results of FAME and rRNA gene sequencing confirmed that the rose strains were members of Xanthomonas, although species identification was not conclusive. MLSA was used to further characterize the rose strains, suggesting that they had considerably low genetic variation, with only two haplotypes, and fell into $X$. axonopodis subgroup $9.2(31,32)$. The final taxonomic rank and species attribution of this pathogen cannot be determined at this point. However, because host range is distinct from the most similar pathovars used in the host range test, this pathogen is suggested to be a new pathovar. The pathovar epithet rosa is proposed according to the nomenclatural decision described previously (6).

Pathogenicity tests are the imperative part in pathovar classification (52). Strains of $X$. axonopodis subgroups are generally grouped into pathovars based on host range and disease symptoms

Table 4. Similarity matrix values (\%) with standard errors derived from concatenated nucleotides between rose strains and their phylogenetically close Xanthomonas spp.

\begin{tabular}{|c|c|c|c|c|c|c|c|c|}
\hline Species & 1 & 2 & 3 & 4 & 5 & 6 & 7 & 8 \\
\hline 1 HDRA (nine rose strains) & & $\ldots$ & .. & .. & .. & ... & .. & ... \\
\hline 2 HDRB (one rose strain) & $99.1 \pm 0.16$ & $\ldots$ & $\ldots$ & $\ldots$ & $\ldots$ & $\ldots$ & $\ldots$ & $\ldots$ \\
\hline \multicolumn{9}{|l|}{3 Xanthomonas alfalfae subsp. alfalfae } \\
\hline ATCC 11765 & $99.1 \pm 0.17$ & $98.3 \pm 0.23$ & & & $\cdots$ & $\ldots$ & $\ldots$ & $\ldots$ \\
\hline 4 X. alfalfae subsp. citrumelonis 1887 & $99.3 \pm 0.14$ & $98.6 \pm 0.19$ & $99.0 \pm 0.19$ & & $\ldots$ & $\ldots$ & $\ldots$ & $\ldots$ \\
\hline 5 X. alfalfae subsp. citrumelonis 1902 & $99.7 \pm 0.10$ & $98.8 \pm 0.19$ & $99.2 \pm 0.17$ & $99.3 \pm 0.15$ & $\ldots$ & $\ldots$ & $\ldots$ & $\ldots$ \\
\hline $6 X$. alfalfae subsp. citrumelonis LMG 9325 & $99.5 \pm 0.12$ & $98.7 \pm 0.20$ & $99.2 \pm 0.17$ & $99.1 \pm 0.18$ & $99.5 \pm 0.13$ & $\ldots$ & $\ldots$ & $\ldots$ \\
\hline $7 X$. perforans ICMP 16690 & $99.5 \pm 0.13$ & $98.5 \pm 0.22$ & $99.0 \pm 0.19$ & $98.9 \pm 0.18$ & $99.4 \pm 0.13$ & $99.4 \pm 0.14$ & $\ldots$ & $\ldots$ \\
\hline 8 X. euvesicatoria ICPB 10461 & $99.3 \pm 0.15$ & $98.4 \pm 0.21$ & $98.9 \pm 0.20$ & $98.9 \pm 0.19$ & $99.2 \pm 0.19$ & $99.1 \pm 0.18$ & $99.0 \pm 0.20$ & $\ldots$ \\
\hline
\end{tabular}


$(32,46)$. The subgroups encompass a group of phytopathogenic strains that cause water-soaked lesions that further develop into necrotic spots and foliar blights across a diverse array of hosts. This phenotypic difference may be associated with genetic heterogeneity (51). MLSA clustered rose strains in X. axonopodis subgroup 9.2 that comprises more than 50 identified pathovars along with $X$. alfalfae, $X$. euvesicatoria, and $X$. perforans based on the gyrB phylogeny (28). Members of the subgroup are considered pathogenic to a wide range of unrelated plant genera (53). Virulence phenotypes of the rose strains on 10 plant species belonging to five plant families were distinct from the other members of the subgroup, forming a unique cluster based on PCA. Moreover, the rose strains were highly aggressive on rose. These findings indicate host-specific characteristics, supporting the pathovar nomenclature for the rose strains.

Similarity data based on concatenated sequences provide a criterion for delimitating species differentiated by DDH. It has been suggested that bacterial species unequivocally assigned by DNADNA reassociation are depicted by sequences with similarities greater than $99 \%$ (51). In contrast, strains sharing concatenated sequence similarities greater than $98 \%$ can also be considered members of the same species (53). The internal similarity value of concatenated DNA sequences for the rose strains of $X$. axonopodis subgroup 9.2 was $99.1 \%$ but those for members of the subgroup were 98.3 to $99.7 \%$, which were slightly less than similarities obtained from concatenated sequences of $d n a K, f y u A, g y r B$, and $r p o D$ gene fragments (51). Therefore, species or subspecies identity may be assigned for the subgroup. The rose strains shared the highest similarity values (98.8 to $99.7 \%$ ) with $X$. alfalfae subsp. citrumelonis, suggesting that they are phylogenetically closer to $X$. alfalfae. However, the virulence phenotype of the rose strains is distinct from X. alfalfae subsp. citrumelonis (Fig. 3). Strains of X. alfalfae subsp. citrumelonis cause water-soaked lesions on citrus but do not infect other hosts (38). Compared with X. alfalfae subsp. citrumelonis, causing poor symptoms, the rose strains resulted in severe chlorosis and necrosis at the injection site of the rose leaf in this study. Although a monophyletic taxon was confirmed for the rose strains based on phylogenetic classifications, polyphasic taxonomy, including phenotypic, chemotaxonomic, genotypic, and biochemical tests, should be used to name a new species or subspecies (52). Further studies need to be performed to determine whether the rose strains are a new species or subspecies. Because the taxonomic revision of $X$. axonopodis subgroups is undergoing, we do not suggest any species name but only a pathovar epithet based on host range tests.

Rose strains have little genetic diversity because they represent only two haplotypes and show 25 polymorphic sites only in the gapA sequence. The 25 mutations in gapA can most easily be explained by a recombination event involving gapA because it is very unlikely that gapA would mutate so fast. The gapA allele was probably acquired by recombination from another strain. To test this hypothesis, we further built a neighbor-net network for members of $X$. axonopodis subgroup 9.2 based on a distance method using SplitsTree v.4 (13) (data not shown). Reticulate evolution was detected, suggesting that recombination between rose strains and other members of the subgroup is possible (14).

The occurrence of the same genotype of bacterial plant pathogens in different regions and populations has been attributed to gene flow or migration $(4,49)$. Nucleotide identity between the two Texas and seven Florida isolates was $100 \%$ for the six gene fragments sequenced, suggesting that migration of this pathogen might have occurred between two rose-growing states. Moreover, the rose stains showing low genetic diversity may result from the recent introduction of this pathogen to the two states. Florida and Texas are 2 of the 15 states growing potted rose plants in the United States., and Florida ranks second nationally, accounting for $\$ 2.57$ million of market value (25). Although the origin of this pathogen is unknown, it has been demonstrated that humans can move pathogens far beyond their natural disseminated restrictions through agricultural practices and trade activities (22). Therefore, the bacte- rium may have migrated between the two states by moving infected rose plants. In addition, exported rootstocks from the two states may be a source inoculum because it is not uncommon to graft a rose variety onto a rootstock against plant diseases. Conversely, the idea that this pathogen evolved from the local population of Xanthomonas spp. cannot be completely ruled out because changes in virulence genes may result in host adaptation and, in turn, a new pathovar $(3,10,18,36,39,41,42,48)$.

In conclusion, MLSA results and pathogenicity tests confirmed that a new pathovar (pv. rosa) of a Xanthomonas sp. was the causal agent of bacterial spot of rose. Although this pathovar shared a high level of DNA sequence similarity with other members of $X$. axonopodis subgroup 9.2, it displayed a virulence phenotype distinct from other similar pathovars of the subgroup used in this study. The species name of the rose strains cannot be determined until more adequate data are established. However, the pathovar epithet rosa is suggested based on its distinct host range from tests in this study.

\section{Acknowledgments}

Research was supported from internal research funds from the University of Florida, Institute of Food and Agricultural Sciences. We thank R. Basler and R. Willis for conducting initial pathogenicity studies and general greenhouse assistance, S. Peters (formerly of Bay Gardens) and D. Hayes of ARIS Horticultural Services (formerly Yoder Brothers) for the donation of 'Knockout' and 'Double Knockout' rose plants for trials, R. Brlansky for supplying citrus plants, G. Denny for supplying ornamental species, J. Mertely and N. Peres for providing clinical isolates, and E. Dickstein for conducting fatty acid analysis.

\section{Literature Cited}

1. Almeida, N. F., Yan, S. C., Cai, R. M., Clarke, C. R., Morris, C. E., Schaad, N. W., Schuenzel, E. L., Lacy, G. H., Sun, X. A., Jones, J. B., Castillo, J. A., Bull, C. T., Leman, S., Guttman, D. S., Setubal, J. C., and Vinatzer, B. A. 2010. PAMDB, a multilocus sequence typing and analysis database and website for plant-associated microbes. Phytopathology 100:208-215.

2. Ausubel, F. M., Brent, R., Kingston, R. E., Moore, D. D., Seidman, J. G., Smith, J. A., and Struhl, K. 1998. Current Protocols in Molecular Biology. John Wiley \& Sons, Hoboken, NJ.

3. Basim, H., Stall, R. E., Minsavage, G. V., and Jones, J. B. 1999. Chromosomal gene transfer by conjugation in the plant pathogen Xanthomonas axonopodis pv. vesicatoria. Phytopathology 89:1044-1049.

4. Boudon, S., Manceau, C., and Nottéghem, J. L. 2005. Structure and origin of Xanthomonas arboricola pv. pruni populations causing bacterial spot of stone fruit trees in western Europe. Phytopathology 95:1081-1088.

5. Chase, A. R., Stall, R. E., Hodge, N. C., and Jones, J. B. 1992. Characterization of Xanthomonas campestris strains from aroids using physiological, pathological, and fatty acid analyses. Phytopathology 82:754-759.

6. Dye, D. W., Bradbury, J. F., Goto, M., Hayward, A. C., Lelliott, R. A., and Schroth, M. N. 1980. International standards for naming pathovars of phytopathogenic bacteria and a list of pathovar names and pathotype strains. Rev. Plant Pathol. 59:153-168.

7. Gent, D. H., Schwartz, H. F., Ishimaru, C. A., Louws, F. J., Cramer, R. A. and Lawrence, C. B. 2004. Polyphasic characterization of Xanthomonas strains from onion. Phytopathology 94:184-195.

8. Gevers, D., Cohan, F. M., Lawrence, J. G., Spratt, B. G., Coenye, T., Feil, E. J., Stackebrandt, E., Van de Peer, Y., Vandamme, P., Thompson, F. L., and Swings, J. 2005. Re-evaluating prokaryotic species. Nat. Rev. Microbiol. 3:733-739.

9. Gonzalez, C., Szurek, B., Manceau, C., Mathieu, T., Séré, Y., and Verdier, V. 2007. Molecular and pathotypic characterization of new Xanthomonas oryzae strains from West Africa. Mol. Plant-Microbe Interact. 20:534-546.

10. Goss, E. M., Kreitman, M., and Bergelson, J. 2005. Genetic diversity, recombination and cryptic clades in Pseudomonas viridiflava infecting natural populations of Arabidopsis thaliana. Genetics 169:21-35.

11. Hamza, A. A., Robène-Soustrade, I., Jouen, E., Gagnevin, L., Lefeuvre, P., Chiroleu, F., and Pruvost, O. 2010. Genetic and pathological diversity among Xanthomonas strains responsible for bacterial spot on tomato and pepper in the southwest Indian Ocean region. Plant Dis. 94:993-999.

12. Huelsenbeck, J. P., and Rannala, B. 1997. Phylogenetic methods come of age: testing hypotheses in an evolutionary context. Science 276:227-232.

13. Huson, D. H. 1998. Splits Tree: analyzing and visualizing evolutionary data. Bioinformatics 14:68-73.

14. Huson, D. H., and Bryant, D. 2006. Application of phylogenetic networks in evolutionary studies. Mol. Biol. Evol. 23:254-267.

15. Jones, J. B., Lacy, G. H., Bouzar, H., Stall, R. E., and Schaad, N. W. 2004 Reclassification of the xanthomonads associated with bacterial spot disease of tomato and pepper. Syst. Appl. Microbiol. 27:755-762.

16. Larkin, M. A., Blackshields, G., Brown, N. P., Chenna, R., McGettigan, P. A., McWilliam, H., Valentin, F., Wallace, I. M., Wilm, A., Lopez, R., Thompson, J. D., Gibson, T. J., and Higgins, D.G. 2007. Clustal W and 
Clustal X version 2.0. Bioinformatics 23:2947-2948.

17. Librado, P., and Rozas, J. 2009. DnaSP v5: a software for comprehensive analysis of DNA polymorphism data. Bioinformatics 25:1451-1452.

18. Lorenz, M. G., and Wackernagel, W. 1994. Bacterial gene transfer by natural genetic transformation in the environment. Microbiol. Rev. 58:563-602.

19. Maiden, M. C. J. 2006. Multilocus sequence typing of bacteria. Annu. Rev. Microbiol. 60:561-588.

20. Maiden, M. C. J., Bygraves, J. A., Feil, E., Morelli, G., Russell, J. E., Urwin, R., Zhang, Q., Zhou, J. J., Zurth, K., Caugant, D. A., Feavers, I. M., Achtman, M., and Spratt, B. G. 1998. Multilocus sequence typing: a portable approach to the identification of clones within populations of pathogenic microorganisms. Proc. Natl. Acad. Sci. USA 95:3140-3145.

21. Mantel, N. 1967. The detection of disease clustering and a generalized regression approach. Cancer Res. 27:209-220.

22. McDonald, B. A., and Linde, C. 2002. Pathogen population genetics, evolutionary potential, and durable resistance. Annu. Rev. Phytopathol. 40:349-379.

23. Miller, J. W. 1997. Xanthomonas leaf spot of Photinia. Plant Pathol. Circ. No. 383. Fla. Dep. Agric. Consum. Serv., DPI, Gainesville.

24. Murray, R. G. E., Brenner, D. J., Colwell, R. R., De Vos, P., Goodfellow, M., Grimont, P. A. D., Pfennig, N., Stackebrandt, E., and Zavarzin, G. A. 1990. Report of ad hoc committee on approaches to taxonomy within the proteobacteria. Int. J. Syst. Bacteriol. 40:213-215.

25. NASS. 2010. Floriculture Crops 2010 Summary. United States Department of Agriculture, National Agricultural Statistics Service. April 2011. Washington, DC.

26. Nei, M. 1987. Molecular Evolutionary Genetics. Columbia University Press, New York.

27. Ngoc, L. B. T., Vernière, C., Jouen, E., Ah-You, N., Lefeuvre, P., Chiroleu, F., Gagnevin, L., and Pruvost, O. 2010. Amplified fragment length polymorphism and multilocus sequence analysis-based genotypic relatedness among pathogenic variants of Xanthomonas citri pv. citri and Xanthomonas campestris pv. bilvae. Int. J. Syst. Evol. Microbiol. 60:515-525

28. Parkinson, N., Cowie, C., Heeney, J., and Stead, D. 2009. Phylogenetic structure of Xanthomonas determined by comparison of gyrB sequences. Int. J. Syst. Evol. Microbiol. 59:264-274.

29. Peakall, R., and Smouse, P. E. 2006. GENALEX 6: genetic analysis in Excel. Population genetic software for teaching and research. Mol. Ecol. Notes 6:288-295.

30. Posada, D. 2008. jModelTest: phylogenetic model averaging. Mol. Biol. Evol. 25:1253-1256.

31. Rademaker, J. L. W., Hoste, B., Louws, F. J., Kersters, K., Swings, J., Vauterin, L., Vauterin, P., and de Bruijn, F. J. 2000. Comparison of AFLP and rep-PCR genomic fingerprinting with DNA-DNA homology studies: Xanthomonas as a model system. Int. J. Syst. Evol. Microbiol. 50:665-677.

32. Rademaker, J. L. W., Louws, F. J., Schultz, M. H., Rossbach, U., Vauterin, L., Swings, J., and de Bruijn, F. J. 2005. A comprehensive species to strain taxonomic framework for Xanthomonas. Phytopathology 95:1098-1111.

33. Roberts, P. D., Berger, R. D., Jones, J. B., Chandler, C. K., and Stall, R. E. 1997. Disease progress, yield loss, and control of Xanthomonas fragariae on strawberry plants. Plant Dis. 81:917-921.

34. Robinson, P. E., Jones, J. B., and Pernezny, K. 2006. Bacterial leaf spot of lettuce: relationship of temperature to infection and potential host range of Xanthomonas campestris pv. vitians. Plant Dis. 90:465-470.

35. Ronquist, F., and Huelsenbeck, J. P. 2003. MrBayes 3: Bayesian phylogenetic inference under mixed models. Bioinformatics 19:1572-1574.

36. Ryan, R. P., Vorhöelter, F.-J., Potnis, N., Jones, J. B., Van Sluys, M.-A., Bogdanove, A. J., and Dow, J. M. 2011. Pathogenomics of Xanthomonas: understanding bacterium-plant interactions. Nat. Rev. Microbiol. 9:344-355.

37. Sahin, F., and Miller, S. A. 1997. Identification of the bacterial leaf spot pathogen of lettuce, Xanthomonas campestris pv. vitians, in Ohio, and assessment of cultivar resistance and seed treatment. Plant Dis. 81:1443-1446.
38. Schaad, N. W., Postnikova, E., Lacy, G. H., Sechler, A., Agarkova, I. Stromberg, P. E., Stromberg, V. K., and Vidaver, A. K. 2005. Reclassification of Xanthomonas campestris pv. citri (ex Hasse 1915) Dye 1978 forms $\mathrm{A}, \mathrm{B} / \mathrm{C} / \mathrm{D}$, and $\mathrm{E}$ as $X$. smithii subsp. citri (ex Hasse) sp. nov. nom. rev. comb. nov., X. fuscans subsp. aurantifolii (ex Gabriel 1989) sp. nov. nom. rev. comb. nov., and $X$. alfalfae subsp. citrumelo (ex Riker and Jones) Gabriel et al., 1989 sp. nov. nom. rev. comb. nov.; X. campestris pv. malvacearum (ex Smith 1901) Dye 1978 as X. smithii subsp. smithii nov. comb. nov. nom. nov.; X. campestris pv. alfalfae (ex Riker and Jones, 1935) Dye 1978 as $X$. alfalfae subsp. alfalfae (ex Riker et al., 1935) sp. nov. nom. rev.; and "var. fuscans" of X. campestris pv. phaseoli (ex Smith, 1987) Dye 1978 as X. fuscans subsp. fuscans sp. nov. Syst. Appl. Microbiol. 28:494-518.

39. Scortichini, M. 2005. The population structure of some plant pathogenic bacteria: an ecological and adaptive perspective. J. Plant Pathol. 87:5-12.

40. Seijo, T. E., Peres, N. A., and Deng, Z. 2010. Characterization of strains of Xanthomonas axonopodis pv. dieffenbachiae from bacterial blight of caladium and identification of sources of resistance for breeding improved cultivars. HortScience 45:220-224.

41. Sikorski, J., Jahr, H., and Wackernagel, W. 2001. The structure of a local population of phytopathogenic Pseudomonas brassicacearum from agricultural soil indicates development under purifying selection pressure. Environ. Microbiol. 3:176-186.

42. Spratt, B. G., and Maiden, M. C. J. 1999. Bacterial population genetics, evolution and epidemiology. Phil. Trans. R. Soc. Lond. B 354:701-710.

43. Swofford, D. L. 2001. PAUP*. Phylogenetic Analysis Using Parasimony (*and Other Methods). v.4 ed. Sinauer Associates, Sunderland, MA

44. Tamura, K., Peterson, D., Peterson, N., Stecher, G., Nei, M., and Kumar, S 2011. MEGA5: molecular evolutionary genetics analysis using maximum likelihood, evolutionary distance, and maximum parsimony methods. Mol. Biol. Evol. 28:2731-2739.

45. Vauterin, L., Hoste, B., Kersters, K., and Swings, J. 1995. Reclassification of Xanthomonas. Int. J. Syst. Bacteriol. 45:472-489.

46. Vauterin, L., Rademaker, J., and Swings, J. 2000. Synopsis on the taxonomy of the genus Xanthomonas. Phytopathology 90:677-682.

47. Wert, T. W., Miller, P., Williamson, J. G., and Rouse, R. E. 2006. Preliminary studies for controlling bacterial spot in low-chill peaches. Proc. Fla State Hortic. Soc. 119:32-33.

48. Yan, S., Liu, H., Mohr, T. J., Jenrette, J., Chiodini, R., Zaccardelli, M., Setubal, J. C., and Vinatzer, B. A. 2008. Role of recombination in the evolution of the model plant pathogen Pseudomonas syringae pv. tomato DC3000, a very atypical tomato strain. Appl. Environ. Microbiol. 74:31713181.

49. Yashitola, J., Krishnaveni, D., Reddy, A. P. K., and Sonti, R. V. 1997. Genetic diversity within the population of Xanthomonas oryzae pv. oryzae in India. Phytopathology 87:760-765.

50. Young, J. M. 2001. Implications of alternative classifications and horizontal gene transfer for bacterial taxonomy. Int. J. Syst. Evol. Microbiol. 51:945953.

51. Young, J. M., Park, D. C., Shearman, H. M., and Fargier, E. 2008. A multilocus sequence analysis of the genus Xanthomonas. Syst. Appl. Microbiol. 31:366-377.

52. Young, J. M., Takikawa, Y., Gardan, L., and Stead, D. E. 1992. Changing concepts in the taxonomy of plant pathogenic bacteria. Annu. Rev. Phytopathol. 30:67-105.

53. Young, J. M., Wilkie, J. P., Park, D.-C., and Watson, D. R. W. 2010. New Zealand strains of plant pathogenic bacteria classified by multi-locus sequence analysis; proposal of Xanthomonas dyei sp. nov. Plant Pathol. 59:270-281.

54. Zwickl, D. J. 2006. Genetic algorithm approaches for the phylogenetic analysis of large biological sequence datasets under the maximum likelihood criterion. Ph.D. thesis, University of Texas, Austin. 